\title{
WARTAWAN MEDIA NOW DALAM MENGEMAS BERITA: PERSPEKTIF SITUATIONAL THEORY
}

\author{
Dasrun Hidayat $^{1}$ dan $^{\text {Anisti }}{ }^{2}$ \\ ${ }^{1}$ Program Studi Ilmu Komunikasi Fakultas Ilmu Komunikasi Universitas BSI \\ Jln Sekolah International 1-6 Antapani Bandung, Telp: 022-7100124, \\ E-mail: dasrun.duh@bsi.ac.id \\ ${ }^{2}$ Akademi Komunikasi AKOM BSI Jakarta \\ Jln Kayu Jati 2 No. 5 Rawa Mangun Jakarta Timur, Telp: 021-29385144, \\ Email: anisti.ans@bsi.ac.id
}

\begin{abstract}
The study aims to map and describe relationships between concepts of activity of journalists in the media now cloning technology based activities and relationship between news reporters. This study discusses the focus of news coverage in media activities and relationships among the journalists in the era of technology. The theory used is situational theory Grunig and Hunt and descriptive method of Public Relations. The study found that the situation changes in the era of media encourage actions of unscrupulous hunters cloning news. News media such as online media should now be used as the initial data is not the primary data news writing. The presence of media now facilitates the work of journalists but not always produce good quality of news. Otherwise, the presence of technology encourages more active cloning news reporter. Media now can initiate active and apathetic public situations as influenced by quality news content. The presence of media technology changes the image of the relationship between journalists - from person to person or reporter to reporter to journalists with media technology.
\end{abstract}

Key words: media now, cloning news, reporter relationship.

\begin{abstract}
Abstrak
Penelitian ini bertujuan untuk memetakan dan mendeskripsikan hubungan antarkonsep tentang aktivitas wartawan di media now berbasis teknologi dalam aktivitas kloning berita dan hubungan antarwartawan. Fokus penelitian ini membahas tentang aktivitas peliputan berita di Media Now dan relationship wartawan di era teknologi. Teori yang digunakan yaitu situational theory Grunig dan Hunt dengan metode deskriptif Public Relations. Hasil penelitian menemukan bahwa situasi perubahan media mendorong tindakan kloning oleh oknum pemburu berita. Berita di Media Now seperti media online semestinya dijadikan data awal bukan data primer penulisan berita. Hadirnya Media Now membangun situasi yakni mempermudah kerja wartawan tapi tidak selamanya menghasilkan pemberitaan yang baik. Justru kehadiran teknologi mendorong oknum wartawan lebih aktif melakukan kloning berita. Media Now dapat melahirkan situasi publik aktif dan apatis karena dipengaruhi kualitas isi berita. Hadirnya teknologi media mengubah citra tentang hubungan antarwartawan. Sebelumnya hubungan person to person atau wartawan dengan wartawan, saat ini wartawan dengan teknologi media.
\end{abstract}

Kata kunci: media now, kloning berita, relationship wartawan.

\section{Pendahuluan}

Lahirnya teknologi informasi juga dibarengi pula oleh tindakan kejahatan berbasis teknolgi atau cyber crime. Bahkan disinyalir teknologi sebagai salah satu faktor mempermudah tindak kejahatan. Misalnya, peniputan, transaksi obat-obat terlarang, eksploitasi perempuan hingga pada kejahatan jurnalistik berbasis teknologi. Penelitian ini fokus pada tindakan kejahatan jurnalistik berbasis media teknologi atau media digital berupa aktivitas kloning atau pengambilan atau pengutipan berita dari sumber lain tanpa menyebutkan sumber beritanya.

Jurnalistik berbasis teknologi adalah kegiatan wartawan, mulai dari penelusuran data, informasi hingga penulisan 
berita dengan menjadikan teknologi sebagai dasar media now menggali data untuk sebuah pemberitaan. Hidayat (2014:95) media now adalah media gabungan atau konvergensi antara media konvensional dan kontemporer berbasis teknologi.

Perubahan situasi konvensional dengan kontemporer salah satunya terletak pada penggunaan teknologi. Diakui, hadirnya teknologi pada media now sangat membantu pekerjaan pewarta. Namun, disisi lain juga adanya realita yang berkembang yakni aktivitas wartawan mengutip berita atau menyadur berita orang lain tanpa menyebutkan sumber. Selain itu, teknologi juga membuat filosofi teori oknum pewarta menjadi tidak difungsikan. Budaya kerja santai, memudahkan cara kerja karena teknologi dianggap dapat memberikan informasi yang mereka butuhkan. Padahal, proses kerja pewarta telah diatur dalam kode etik jurnalistik. Salah satunya mengatur tentang peliputan. Disebutkan diantara bentuk kejahatan di dunia peliputan yaitu pengambilan berita tanpa menyebutkan sumber. Situasi ini sangat dirasakan ketika hampir disetiap media now menurunkan pendapat dari narasumber yang sama terkait isu yang sama pula. Padahal kenyataannya narasumber hanya diwawancarai oleh satu atau dua media saja. Artinya tidak semua wartawan hadir ketika adanya wawancara atau konferensi pers. Menyebarnya informasi tersebut, diduga akibat perilaku oknum yang mengambil, mengutip berita dari sumber utama tanpa menyebutkan sumbernya. Media now berbasis teknologi dijadikan sebagai rujukan karena dinilai lebih cepat dalam pemberitaan dibandingkan media lainnya.

Teknologi pada media now dan media baru, tidak dapat dipungkiri telah mengakibatkan terjadinya hibridisasi informasi. Dylko dan McCluskey
(2014:502) hibridisasi yaitu mengurangi kemampuan peneliti berteori tentang efek yang ada dari bentuk media karena tumpang tindih substansial dalam teknologi karakteristik media. Selain itu, Teknologi Informasi Komunikasi (TIK) mengubah perilaku individu dengan cepat. Karpf (2011:503) fenomena penggunaan forum diskusi seperti blog, jejaring sosial, dan microblogging genre media, semuanya pindah ke platform mobile. Hibridisasi tersebut salah satunya mendorong terjadinya instansisasi peliputan dan akhirnya melakukan tindakan kloning berita.

Kloning berita merupakan istilah yang sudah cukup akrab dikalangan insan media dan masyarakat umum. Namun di dunia wartawan sendiri tidak pernah sepakat tentang istilah tersebut. Kloning artinya mengambil, meniru, menyamakan isi berita dengan media lainnya. Tindakan ini menjadi suatu yang melanggar kode etik jurnalistik ketika proses peliputan tidak menyebutkan asal atau sumber berita. Namun, berbeda istilahnya apabila sumber berita disebutkan, yakni wartawan melakukan re-write atau menulis ulang berita dengan merujuk pada sumber berita.

Wartawan adalah sebutan lain dari para pemburu berita, juru warta, reporter, news gatter dan lainnya. Di dunia wartawan, mengenal dan mengakui adanya hubungan wartawan sebagai salah satu strategi berbagi informasi atau berita antar wartawan media massa. Pada dasarnya adalah sama, yakni proses tukar-menukar berita, namun jika menggunakan istilah kloning berita selalu merujuk pada kejahatan berita, yakni mengambil berita orang lain tanpa menyebutkan sumber asli berita tersebut. Sedangkan, tukar menukar informasi, merupakan aktivitas yang sama, namun menyebutkan sumber berita.

Fenomena kloning berita memang 
terjadi dan tidak dapat dipungkiri bahwa ada saja "oknum" wartawan yang berlindung pada kekuatan lembaga media. Sebuah kejahatan dalam dunia wartawan karena telah merampas hak pemilik berita tanpa izin. Adanya praktik kloning berita ini, disinyalir terjadi karena lemahnya aturan yang diterapkan pada internal media. Tidak adanya saksi yang tegas dari eksternal yakni lembaga pers atau dewan pers terhadap tindakan kloning berita tersebut, disamping karena kurangnya pengetahuan redaktur sehingga sulit membedakan hasil kloning dan buatan wartawanya. Tentu saja faktor pengetahuan wartawan serta kegigihan wartawan juga sangat mendominasi terjadinya kejahatan kloning berita.

Tren kloning berita bisa saja dilakukan secara sadar maupun tidak disadari, seiring hadirnya media online, sehingga mempermudah insan pers untuk menangkap isu berita. Terkadang media online dimanfaatkan oleh oknum yang enggan meliput kelapangan. Misalnya, cukup hanya mengupdate berita melalui telepon kantor atau telepon pribadi. Hal ini berdampak tidak baik bagi dunia pemberitaan karena mengakibatkan proses kegiatan jurnalistik menjadi mandul, tidak berfungsi sesuai dengan kaidah media massa. Misalnya, mulai dari rapat redaksi untuk menentukan topik berita yang akan diangkat, menentukan nara sumber, hunting hingga pada proses penulisan dan penerbitan. Seyogyanya tahap demi tahap tersebut dilakukan secara normal, namun adanya media online sangat memicu kerja istans para jurnalis atau wartawan. Semua tahapan dipotong menjadi singkat bahkan secara menyengaja mengcopi atau mengkloning berita tanpa menyebutkan sumber berita. Tindakan instan wartawan tersebut sangat mempengaruhi kualitas isi atau content media massa sehingga aspek tanggung jawab terhadap pemberitaan yang akurat dan bermanfaat jauh dari harapan sebenarnya. Wartawan tidak lagi mengindahkan fungsi media massa sebagai sarana informasi utama masyarakat yang dinilai bertanggung jawab. Masyarakat saat ini terdorong untuk lebih kritis mengonsumsi isi berita dan selektif dalam memilih saluran media massa. Hal ini pula yang menyebabkan reputasi dan citra wartawan dan media massa tertentu menjadi kurang baik dimata masyarakat. Pergeseran fungsi hubungan wartawan di era digital ini, menarik untuk ditelaah dan dibahas dalam artikel ini sehingga menemukan jawaban atas permasalahan tentang kloning atau aktivitas mengambil berita tanpa mencantumkan sumbernya.

\section{Metode Penelitian}

Penelitian ini menggunakan metode deskriptif Public Relations (PR) yang bertujuan untuk mengetahui penilaian orang lain atau publik terhadap wartawan dan media terhadap fenomena kloning berita di era digital. Menurut Ardianto (2013:320) PR sangat sering menggunakan penelitian deskriptif. Metode ini diaplikasikan untuk isu-isu sosial lebih luas, seperti pembentukan opini publik. Di dunia PR metode deskriptif terdiri dari survei deskriptif, meneliti gambaran situasi atau kondisi yang terjadi sekarang, dan survei eksplanatori atau penjelasan, dikenal dengan metode penelitian sebabakibat. Metode ini tujuannya untuk mencoba menjelaskan keberadaan situasi dan kondisi sekarang serta memberikan penjelasan tentang opini dan sikap publik.

Pendekatan yang relevan pada penelitian ini adalah pendekatan kualitatif. Pendekatan kualitatif menekankan pada makna, penalaran, definisi suatu situasi tertentu dalam konteks tertentu, lebih banyak meneliti hal-hal yang berhubungan dengan kehidupan sehari-hari. Pendekatan kualitatif, lebih lanjut mementingkan 
proses dibandingkan dengan hasil akhir. Urutan-urutan kegiatan dapat berubah sewaktu-waktu tergantung pada kondisi dan banyaknya gejala-gejala yang ditemukan. Pendekatan ini diarahkan pada latar dan individu secara holistik atau utuh. Kualitatif secara epistimologi menekankan pada asumsi tentang hubungan peneliti dengan masalah yang diteliti, yaitu keterlibatan langsung dengan masalah yang diteliti.

Penelitian kualitatif menekankan sifat realita yang terbangun secara sosial, hubungan erat antara peneliti dengan subjek yang diteliti dan penekanan pada makna situasi penyelidikan. (Denzin: 2009:06).

Miller menekankan pada epistimologi penelitian yaitu hubungan peneliti dengan masalah yang diteliti yakni bersifat subjektif. Artinya peneliti berada di dalam (internal) penelitian. Keterlibatan langsung diharapkan dapat membantu peneliti dalam menggali data lebih mendalam. Selain itu, kualitatif menekankan pada seting yang alami atau natural setting (2005:15).

Penelitian ini mencoba untuk melakukan interpretasi terhadap realita kloning berita di era digital. Realtias yang dibangun dengan tujuan untuk memahami opini dan sikap publik terhadap realitas tersebut. Diharapkan pendekatan interpretatif dapat menggambarkan secara holistik tentang masalah yang terjadi yakni kegiatan kloning dan penyaduran berita dari sumber berita lainnya. Realitas dibangun secara alami berdasarkan datadata yang dikumpulkan dari pengamatan selama melakukan penelitian di lapangan. Adapun informan penelitian ditentukan secara purposive sampling. Informan berprofesi sebagai wartawan media now di kota Bandung.

\section{Hasil Penelitian dan Pembahasan}

Pada bagian ini penulis memaparkan beberapa unit analisis dari masalah penelitian tentang “Wartawan Media Now dalam Mengemas Berita Online". Unit analisis yakni kesan yang dibangun dalam aktivitas kloning berita di media online dan relationship wartawan di era digital. Diharapkan unit yang dianalisis ini dapat menjawab permasalahan penelitian. Ada beberapa literatur review yang dijadikan sebagai tinjauan kajian ini. Beberapa kajian yang dikutip dari jurnal international menggambarkan tentang kehadiran teknologi dan dampaknya, meskipun tidak ada yang mengangkat secara spesifik tentang cloning berita.

Alasan yang baik untuk memeriksa kembali metodologis dan teoritis kerangka kerja yang mendominasi disiplin komunikasi hari ini (Bennett \& Iyengar, 2008; Lang, 2013). Misalnya, lingkungan komunikasi saat ini ditandai dengan hibridisasi besar media yang ada: berita koran Situs web sering menggabungkan forum diskusi, seperti menggabungkan fungsi konten-sharing, situs web juga menggabungkan blogging fitur, dan sebagainya (Karpf, 2011:503). Dylko dan McCluskey (2014:502) berpendapat bahwa seperti hibridisasi mengurangi kemampuan peneliti berteori tentang efek yang ada dari bentuk media karena tumpang tindih substansial dalam teknologi karakteristik media. Selain itu, Teknelogi Informasi Komunikasi TIK mengubah perilaku individu dengan cepat. Hal ini dapat dilihat dari fenomena penggunaan forum diskusi seperti blog, jejaring sosial, dan microblogging genre media, yang semuanya sekarang pindah ke platform mobile. Dylko dan McCluskey (2014:501) menyatakan bahwa percepatan seperti pembangunan ICT dapat mengurangi kemampuan teori sehingga memunculkan dampak media dimasa mendatang.

\section{Kesan Media Now Dimata Publik}

Hidayat dalam bukunya Media Cyber Public Relations (2014:95) media now merupakan media berbasis teknologi internet. Konvergensi atau 
penggabungan media konvensional dengan kontemporer. Teknologi baru yang mendorong kerja lebih praktis, cepat dan ekonomis. Hampir semua perusahaan menggunakan media online sebagai akses informasi, tak terkecuali media massa. Media online seringkali dijadikan sebagai data primer oleh wartawan tanpa melakukan croschek dari sumber berita. Wartawan dengan mudahnya melakukan copy paste berita tanpa menyebutkan sumber pengutipan. Data media online seharunya tidak dijadikan sebagai data primer tapi sebagai data awal saja atau pijakan wartawan untuk mencari berita di lapangan. Namun pada kenyataannya ada saja oknum pewarta bertindak curang sehingga berita yang diangkat dimedia online seringkali sama dengan media online lainnya.

"Seharusnya pada saat kloning berita wartawan hendaknya menyebutkan sumber, melakukan konfirmasi sebelum menulis berita. Kloning memang ada dan hal ini terjadi antar sesama media online maupun dengan media cetak. Realitas kloning berita memang sering terjadi namun, hal ini terjadi pada kondisi darurat dengan alasan dikejar deadline dan memang seringkali disalahgunakan dengan seolah-olah berita yang ditulis berasal dari liputan si wartawan langsung. Sebetulnya kalo disebutkan sumber bukan kloning tapi pengutipan dari sumber awal atau sekunder yang harus dikembangkan lagi ke lapangan dan wawancara dengan sumber berita." Hasil wawancara informan 11 Maret 2015.

Kloning berita pada realitasnya tidak terjadi secara masif, hanya oknum pewarta yang ingin mendapatkan berita secara instan dengan berlindung pada "deadline" sehingga menutup mata dengan standar pemberitaan. Di dunia wartawan tidak membenarkan tindakan kloning berita, tapi dibenarkan istilah pengutipan atau menyadur data dari berita media lain untuk dijadikan sebagai data awal yang dapat dikembangkan sebagai bahan berita baru atau lanjutan dari media sebelumnya (update news). Istilah lainnya adalah follow up news atau berita pengembangan dari sumber awal dengan sudut pandang berbeda. Hadirnya media online seharusnya dijadikan sebagai data awal sehingga penting bagi wartawan untuk melakukan konfirmasi atas kebenaran informasi tersebut.

Kegiatan kloning berita sebenarnya dapat dideteksi sejak dini oleh redaktur, karena sebagai gatekeeper, redaktur memiliki pengatahuan dan pengalaman yang lebih dibandingkan wartawan. Selain itu, redaktur seharusnya lebih berhati-hati terhadap hasil pekerjaan para awak media. Sangat disayangkan kegiatan menyadur berita dari media online, justru seringkali ide awalnya dari redaktur. Redaktur meminta untuk mengambil dari sumber orang lain, dengan catatan direkonstruksi dengan merubah lead dan menambahkan sumber berita. Kepercayaan redaktur malah disalah gunakan, sehingga akhirnya terjadi kloning berita. Ditambah lagi kurangnya kontrol dari redaktur atas hasil kerja dari para awak media.

"Iya redaktur nggak bisa nutup mata kalo ada wartawannya melakukan kloning berita karena redaktur yang seringkali memberikan ide awal dari media online. Hanya saja wartawan malas dan tidak mengerjakan sesuai dengan keinginan redaktur. Parahnya lagi pada saat naik cetakataudipublikasikan redakturkurang ditel mengeceknya. Seharusnya memang redaktur gerbang terakhir mengecek isi berita yang dapat dipertanggung jawabkan." Hasil wawancara informan 11 Maret 2015.

Kloning berita sudah menjadi realitas di dunia wartawan bahkan menjadi sebuah kebudayaan karena telah menjadi kesepakatan yang secara tidak formal bagi sebahagian wartawan. Meskipun ada wartawan yang menolak keras tindakan kloning berita karena dinilai sebagai kejahatan jurnalistik. Upaya kloning 
meskipun tidak ada kesepakatan antar media dan wartawan, antar owner media dan lainnya. Tindakan kloning berita juga tidak terstrukutur melainkan mengalir karena faktor kebutuhan berita yang seringkali sulit untuk dicapai, disamping faktor lain seperti efisiensi dan kemalasan wartawan.

Kehadiran media now secara tidak sadar telah membangun situasi baru yaitu situasi dimana wartawan dikondisikan untuk pragmatis dan tidak aktif. Gruning dan Hunt dalam teorinya situational theory menegaskan bahwa dampak dari situasi yang diciptakan dapat berupa positif dan negatif. Publik selalu aktif mengamati dan mencerna setiap informasi yang disampaikan. Demikian pula publik akan bersikap apatis ketika publik tidak menemukan informasi yang dapat dipertanggung jawabkan. Dikhawatirkan aktivitas kloning berita juga dapat berdampak pada situasi publik. Muncul ketidak percayaan terhadap pemberitaan sehingga publik lebih memilih apatis.

\section{Relationship Wartawan Media Now}

Wartawan di era digital didorong agar mampu bekerja dengan memadukan kemampuan antara konsep kewartawanannya dengan perkembangan update tentang media now. Tidak dapat dipungkiri kehadiran teknologi sangat membantu pekerjaan wartawan di media now. Membantu wartawan dalam mengenali dampak dari teknologi yang berkembang saat ini. Selain itu, wartawan juga dapat memprediksi dan menggambarkan kunci dari industri teknologi yang relevan dengan praktik jurnalistik disetiap dan jenis media. Disamping itu, wartawan juga mampu mengidentifikasi khalayak sasaran industri teknologi serta memahami secara detail tentang program-program dari teknologi yang dapat digunakan dalam praktik jurnalistik. Hal ini untuk mengidentifikasi prinsip-prinsip kunci kerja melalui teknologi sehingga dapat membimbing praktik jurnalistik di era industri teknologi. Wartawan Update dengan teknologi tentunya diharapkan dapat mengenali aplikasi dari prinsipprinsip teknologi melalui studi kasus yang berkembang sehingga dari kasus tersebut dapat diambil beberapa prinsip yang memiliki kemiripan sebagai contoh skenario atau cara kerja wartawan.

Hal serupa dipertegas oleh Tench and Yeomans (2006:483) dalam bukunya Exploring Public Relations; recognise of this impact of technologi, describe the key features of the technology industry relevant to public relations practice, identify the audiences targeted by the technology inustry, detail the features of the industry that challenge public relation practice, identify key principles guiding the practice of public relations in the technology industry, recognise applications of these principles through case studies, apply some of these priniples to example scenarios.

Profesi sebagai wartawan dituntut untuk memahami dengan baik tata cara kerja untuk memaksimalkan isi berita sesuai dengan fakta yang ada dan menggunakan bahasa yang baik dan benar dengan dilandasi oleh rasa tanggung jawab dan beretika. Wartawan dapat dikelompokkan sebagai wartawan profesional, freelance, koresponden dan wartawan kantor berita. Semua jenis wartawan pada prinsipnya bertugas sebagai jurnalis untuk mencari informasi dan disampaikan kepada masyarakat.

Kesamaan profesi sebagai wartawan menjadi salah satu faktor penyebab kedekatan hubungan antar jurnalis. Adanya rasa senasib-sepenanggungan, kesamaan tanggung jawab mendorong terbentuknya kebersamaan. Hal ini dilakukan semata-mata untuk saling mendukung profesi mereka. Akan tetapi, pada realitasnya kebersamaan tersebut ada yang menyalahartikan sehingga fungsinya pun disalah gunakan. 
Misalnya, hubungan dijadikan sebagai alat untuk mempermudah pencapaian target berita dengan melakuan kloning berita, mengutip, mengambil berita orang lain tanpa menyebutkan sumber aslinya. Jalan pintas atau instanisasi seperti ini memang terjadi, seiring dengan beban atau target pemberitaan yang ditetapkan oleh redaktur berita. Saat ini kloning berita terjadi begitu mudah seiring hadirnya teknologi. Semua serba praktis sehingga media dan wartawan terkadang tidak ingin direpotkan dengan proses peliputan yang panjang dan biaya yang besar seperti zaman sebelum hadirnya media online.

Kehadiran media now juga membangun situasi baru terhadap cara kerja wartawan. Wartawan saat ini menganggap hubungan atau relationship yang paling dekat adalah teknologi. Terjadi perubahan sikap dan perilaku wartawan seiring dengan perkembangan teknologi sehingga tidak bisa dipungkiri bahwa citra atau image wartawan saat ini terkesan pragmatis hanya memperhatikan tujuan dan manfaat tanpa mengedepankan proses yaitu standar dan etika peliputan. Gruning dan Hunt dalam situational theory berasumsi bahwa situasi yang dibangun akan mendorong terjadinya dua kemungkinan yaitu publik aktif atau apatis terhadap informasi yang disampaikan. Situasi apatis juga tidak hanya berdampak pada publik dari media massa akan tetapi situasi yang dibangun pada media now juga membangun sikap apatis antar wartawan. Satu dengan lainnya seperti tidak membutuhkan karena merasa adanya teknologi yang dapat membantu aktivitas mereka. Situasi dengan kehadiran teknologi di media now ini tentu saja sangat mempengaruhi hubungan atau relationship wartawan.

Perubahan situasi dari sebelumnya wartawan lebih mengenal istilah kontributor pemberitaan yang ada disetiap daerah, namun saat ini situasi beralih kepada teknologi media. Sangat disayangkan, apabila teknologi media now dijadikan sebagai rekan kerja utama. Padahal, relasi yang perlu dibangun adalah relasi antar wartawan untuk kepentingan tukar-menukar informasi yang lebih akurat. Artinya pertukaran informasi sebagai data awal yang dapat dikembangkan lebih mendalam oleh para wartawan sesuai dengan kebutuhan dari masing-masing media.

"Dulu mah kita ngga mengakui adanya kloning berita, yang ada dulu sistem kontributor berita, menempatkan wartawan sebagai perwakilan di setiap daerah. Tujuannya untuk menghendel pemberitaan daerah tanpa yang di pusat repot-repot mengerjakannya lagi. Tapi, sekarang hanya media-media tertentu yang masih bertahan menempatkan kontributor, justru kebanyakan media sekarang menarik kontributor dengan alasan penghematan, tidak efektif dan lainnya. Saat ini media lebih memilih berhubungan dengan media online sebagai rujukan bahkan bahan utama pemberitaan. Nah ini yang sebenarnya saya secara pribadi menolak, karena dapat merusak citra wartawan. Semestinya, proses jurnalistik tetap harus dijalankan sesuai dengan kaidahnya. Tapi, lagilagi media maupun wartawan nggak mau repot ...iya begini akhirnya." Hasil wawancara informan 17 Maret 2015.

Pergeseransituasihubungan wartawan tentu merubah perilaku wartawan. Jika sebelumnya terjadi jaringan informasi berbasis wartawan dengan wartawan atau person to person, namun saat ini jaringan yang terbentuk adalah wartawan dengan teknologi. Sejak adanya media now merubah cara pandang wartawan dengan mengutamakan media online sebagai sumber bukan wartawan atau koresponden di daerah. Meskipun masih ada media yang mempertahankan kebijakan koresponden sebagai sumber berita di setiap daerah.

Mencermati cara wartawan media now dalam mengemas berita, sebenarnya jauh sebelum teori situasional ini hadir, McLuhan melalui teori ekologi media 
dalam Griffin (2011:324) dijelaskan bahwa perkembangan media akan merubah perilaku individu. Di awali dari era tribal, literasi, cetak hingga elektronik. Setiap era media tentu saja melahirkan generasi yang berbeda. Demikian pula perkembangan media di era elektronik yang telah mengarah pada era digital. McLuhan mengilustrasikan seperti kampung besar, artinya bahwa jarak komunikasi tidak menjadi hambatan. Meskipun dibatasi ruang dan waktu, namun satu dengan lainnya seolah berada dalam satu tempat. Hal ini pula yang dirasakan oleh para wartawan media now. Mereka menilai bahwa teori tentang kegiatan peliputan harus ke lapangan secara langsung, saat ini sudah mulai diabaikan. Mereka lebih memilih membangun hubungan melalui media now berbasis teknologi.

Perubahan sifat hubungan wartawan dari wartawan ke teknologi, dikhawatirkan dapat memperkuat citra tentang buruknya kualitas pemberitaan, sehingga publik akan lebih apatis. Selain itu, menjadi konstruksi publik seakan membenarkan adanya praktik kloning berita, meskipun jika ada hal ini dilakukan oleh para oknum. Sebenarnya di dunia wartawan tidak mengakui adanya kloning berita, tapi lebih kepada tukaran informasi sesama wartawan atau menjadikan media lain sebagai sumber berita sekunder. Jika memang ada kloning berita secara terang-terangan itu dilakukan oleh oknum yang biasanya terjadi dimedia "tanda kutip" hal ini terjadi karena tidak ada kontrol dan pengetahuan dari redaktur serta aturan main dari perusahaan internal media yang tidak tegas untuk menetapkan punishment.

"Sebenarnya harus ada kontrol dari redaktur sebagai gatekeeper, tapi sayangnya justru terkadang redaktur yang meminta ke wartawan untuk melakukan kloning berita. Nggak ada ketegasan dari redaktur justru seolaholah mendukung perilaku wartawan. Semestinya redaktur tegas, dikeluarkan aturan internal agar wartawan takut melakukan tindakan yang melanggar." Hasil wawancara informan 11 Maret 2015.

Kegiatan dan hubungan antar wartawan diakui lebih baik sebelum adanya peran teknologi. Jika ditinjau dari aspek tanggung jawab terhadap isi berita, seringkali wartawan saat ini terlalu terburuburu untuk mempublikasikan tanpa melakukan croschek terlebih dahulu. Berbeda dengan era konvensional, wartawan benarbenar bekerja keras, membangun hubungan dengan wartawan di setiap daerah, seperti kabupaten-kabupaten sebagai titik sumber berita daerah. Namun, saat ini hubungan atau relationship wartawan seakan sudah dianggap tidak penting. Justru teknologi yang dijadikan sebagai wujud "wartawan" baru bagi para wartawan itu sendiri. Mereka lebih percaya dengan berita yang disampaikan oleh media online sehingga dijadikan rujukan pemberitaan dimedia lainnya.

Selain bergesernya fungsi hubungan antar wartawan, hadirnya teknologi pada media now juga mengakibatkan kompetensi wartawan menjadi menurun. Akibatnya lahir wartawan-wartawan yang tidak memiliki kemampuan sehingga dalam menjalankan tanggung jawabnya selalu melakukan tindakan instan seperti kloning berita. Ulah beberapa oknum wartawan tersebut sangat mempengaruhi citra keberadaan media massa pada umumnya. Kegiatan kloning berita dengan tidak menyebutkan sumber berita menjadi masalah lama yang belum tuntas di lingkungan budaya kerja media. Budaya yang secara tidak sengaja atau memang telah disepakati untuk melakukan tukarmenukar berita sehingga realitas ini menjadi bahan konstruksi wartawan media massa dan publik.

\section{Simpulan}

Kehadiran media now merubah situasi cara kerja wartawan atau para pemburu berita. Cara yang instan sehingga 
memperkuat adanya aktivitas kloning berita. Situational theory menekankan bahwa situasi perubahan cara kerja wartawan dapat menimbulkan dua kemungkinan yaitu publik aktif dan publik apatis terhadap informasi. Media now berbasis teknologi semestinya dijadikan sebagai data awal atau sekunder, bukan ditiru dan dijadikan data utama tanpa melakukan pembaharuan terhadap isi berita. Kesan yang terbangun adalah bahwa media now menjadi sumber utama berita sehingga terjadi pergeseran hubungan wartawan dalam menempatkan relasi berita. Jika sebelum hadirnya media now hubungan yang dibangun antar wartawan, saat ini wartawan membangun hubungan dengan teknologi media.

\section{Daftar Pustaka}

Ardianto, Elvinaro. (2011). Handbook of Public Relations. Bandung: Simbiosa Rekatama Media

Ardianto, Elvinaro. (2010). Metodologi Penelitian Untuk Public Relations. Bandung: Simbiosa Rekatama Media.

Cutlip, Center, Broom. (2011). Effective Public Relations: Edisi Kesembilan. Jakarta: Kencana.

Craig, Muller. (2007). Theorizing Communication. United Kingdom: Sage Publications.

Denzin, Lincoln. (2012). Hand Book of Qualitative. Jogjakarta: Pustaka Pelajar

Griffin, EM. (2011) A First Look At Communication Theory. Eighth Edition.USA: Mc Graw Hill.
Hidayat, Dasrun. (2014). Media Public Relations: Pedekatan Studi Kasus Cyber Public Relations sebagai Metode Kerja PR Digital. Jogjakarta: Graha Ilmu.

Shoemaker, Pamela. Reese. D Stephen. (1996). Mediating The Message. USA: Logman Publishers.

Tench, Ralph. Yeomans, Liz. (2006). Exploring Public Relations. England: Peason EZducation Limited.

\section{Referensi Journal International}

Bennett, W. L., \& Iyengar, S. (2008). A new era of minimal effects? The changiof political communication. Journal of Communication, 58, 707-731.

Eveland, W. P. (2003). A "mix of attributes" approach to the study of media ecommunication technologies. Journal of Communication, 53, 395-410.

Dylko. (2014). Using Technological Attributes to Study Online Media: The Case of User-Generated Content. Journal of Broadcasting \& Electronic Media 58(4), pp. 501-521. ISSN: 0883-8151 print/1550-6878 online.

Dylko, I. B., Beam, M., Landreville, K., \& Geidner, N. (2012). Filtering 2008 presidential election news on YouTube by elites and nonelites: An examination of the democratizing potential of the Internet. New Media \& Society, 14, 832-84.

Dylko, I. B., \& McCluskey, M. (2012). Media effects in an era of rapid technological transformation: A case of user-generated content and political participation. Communication Theory, 22, 250-278. 